\title{
Earthquake Statistics and Earthquake Research Studies in Pakistan
}

\author{
Farhana Sarwar1,2, Saleem Iqbal2*, Muhammad Qaisar ${ }^{3}$, Abdul Rehman', Faiza Akhtar4, \\ Syed Mohsin Raza ${ }^{5}$ \\ ${ }^{1}$ FG Girls Degree College, Quetta, Pakistan \\ ${ }^{2}$ Department of Mathematics, University of Balochistan, Quetta, Pakistan \\ ${ }^{3}$ Center for Earthquake Studies, NCP, Quaid-e-Azam University, Islamabad, Pakistan \\ ${ }^{4}$ Government Girls Polytechnic Institute, Quetta, Pakistan \\ ${ }^{5}$ Department of Physics, University of Balochistan, Quetta, Pakistan \\ Email:f_saleem10@yahoo.com, "saleemiqbal81@yahoo.com, mqaisar49@gmail.com, \\ abdul_maths@yahoo.com, faizaakhtar42@yahoo.com, smraza7@yahoo.com
}

Received 2 February 2016; accepted 15 May 2016; published 18 May 2016

Copyright (C) 2016 by authors and Scientific Research Publishing Inc.

This work is licensed under the Creative Commons Attribution International License (CC BY).

http://creativecommons.org/licenses/by/4.0/

(c) (i) Open Access

\begin{abstract}
This paper is about short review of earthquake statistics and efforts for earthquake mitigation, hazard and risk assessment studies in Pakistan. Pakistan and adjoining region lying between longitude $60^{\circ} \mathrm{E}$ to $78^{\circ} \mathrm{E}$ and latitude $20^{\circ} \mathrm{N}$ to $45^{\circ} \mathrm{N}$ are selected for the study as this region has a history of many large earthquakes because of its location in the region of intersection of three plates namely Indian, Eurasian and Arabian Sea plate. This paper is based on the study of both seismological history of the region which includes recent and historical seismicity based on earthquake catalogue as well as geological knowledge supplemented with available fault system information. In this study, Pakistan and adjoining regions are divided into 14 seismogenic zones. Seismicity of each zone is studied considering also the major cities in the respective zone and type of infrastructure which is mainly responsible for earthquake disaster rather than earthquake itself.
\end{abstract}

\section{Keywords}

Seismicity, Active Faults, Seismogenic Zones, Tectonic Plates

\section{Introduction}

Pakistan has a history of many large earthquakes and its various regions are at high seismic risk due to presence of numerous active faults as the area under consideration is situated on a known high seismic belt bordering "Corresponding author.

How to cite this paper: Sarwar, F., Iqbal, S., Qaisar, M., Rehman, A., Akhtar, F. and Raza, S.M. (2016) Earthquake Statistics and Earthquake Research Studies in Pakistan. Open Journal of Earthquake Research, 5, 97-104. 
various active plates and it has been shown in [1], that over $90 \%$ of the world's seismicity occurs within comparatively close belts where two or more of the tectonic plates slide past or collide with each other. Based on geological and geomorphological evidence, many seismological sources have been recognized in Pakistan [2].

In this paper, both the seismological and geological history of the region has been taken into account, which is based on earthquake catalogue and associated fault system in the region. Geologically Pakistan overlaps two tectonic plates, Eurasian plate and Indian plate. On the north-western edge of Indian plate lies Punjab and Sindh, the Khyber-Pakhtunkhwa and Balochistan lie within the Eurasian plate whereas Azad Kashmir and Northern Areas are prone to strong earthquakes as they lie where two tectonic plates collide. Unfortunately not much attention is being paid to earthquake studies and research work in Pakistan. It was only after 2005 Muzaffarabad earthquake that the government realized the importance of earthquake studies but unfortunately for a short time period. The more recent Ziarat earthquake on 28 October 2008 of M 6.4, Awaran district Balochistan earthquake on September 24, 2013 of M 7.8 and Awaran district Balochistan earthquake on September 28, 2013, M 6.8 and on 26 Oct 2015 of magnitude 7.6 struck northern areas, and all these earthquakes all over the country had created a threat to the human society.

Earthquake Prediction studies is not getting much attention and hence is not an active research field in Pakistan as in other countries prone to earthquake, this is because most of the seismologists in Pakistan take earthquake prediction as fool's paradise and focus only on the earthquake hazard studies and therefore in the past, few hazard maps based on probabilistic approach which is defined as the likelihood for a specified Peak Ground Acceleration (PGA) value to be exceeded within a certain time interval are available for the region but unfortunately the drawback of this approach is that catalogue completeness is very essential parameter in this technique and we may be underestimating the seismicity in those seismogenic zones where the strongest occurring event is not reported in the catalogue, in addition to this, other aspects largely overlooked in this approach are that the effects of crustal properties on attenuation are neglected and the ground motion parameters are derived from overly simplified attenuation functions, and a partisan solution to this problem is field studies aimed at the recognition of the seismogenic potential of major active faults. As shown in this paper, it is required that reasons for main destruction due to these earthquakes may be addressed properly like implementation of building code especially in areas lying on the active faults as many thickly populated major cities of Pakistan like Islamabad, Quetta, Muzaffarabad etc. lie on active faults that are source of many destructive earthquakes in the past. It is also immediate need that individual as well as Government supported Earthquake safety and preparedness training programs should be organized in order to save lives and properties.

\section{Method}

Pakistan is the most seismically active regions of Asia because of the presence of a number of active faults. For thorough study of seismicity and hazard investigation, earthquake catalogues plays a vital and significant role as it provides a systematic record of recent and historical seismicity therefore it is prerequisite to examine the completeness and uniformity of the catalogue. The earthquake catalogue has been analyzed for the studied region by Farhana et al. in [3] and the same catalogue is also used in this study. We have divided the entire region of study comprising Pakistan and adjoining regions of Iran, Afghanistan, Tajikistan, China, India into 14 seismogenic zones, which represent areas that are characterized by specific parameters that are assumed to be homogeneous within the zone, these parameters are

- The level of seismicity

- Tectonic behavior

- Stress dominance

We have shown in our studies that the advantage of this zoning is that the cities lying on the active faults can be prevented from destruction from future disaster by proper planning of infrastructure and by growing knowledge and awareness in common man to take safety precautions. The seismogenic zones are very dense along the collision plate boundary, i.e. along the Kirthar Suleiman Hindu Kush, Himalaya [4]. Figure 1 shows fourteen (14) seismogenic zones and the spread of seismicity according to the catalogue used in our studies for a period of 100 years for these 14 zones is shown in Figure 2.

\section{Result and Discussion: Active Fault System in the 14 Seismogenic Zones}

A number of active faults have been identified in Pakistan [5]. It has been established that the major faults of 
$59^{\circ} 60^{\circ} 61^{\circ} 62^{\circ} 63^{\circ} 64^{\circ} 65^{\circ} 66^{\circ} 67^{\circ} 68^{\circ} 69^{\circ} 70^{\circ} 71^{\circ} 72^{\circ} 73^{\circ} 74^{\circ} 75^{\circ} 76^{\circ} 77^{\circ} 78^{\circ} 79^{\circ}$

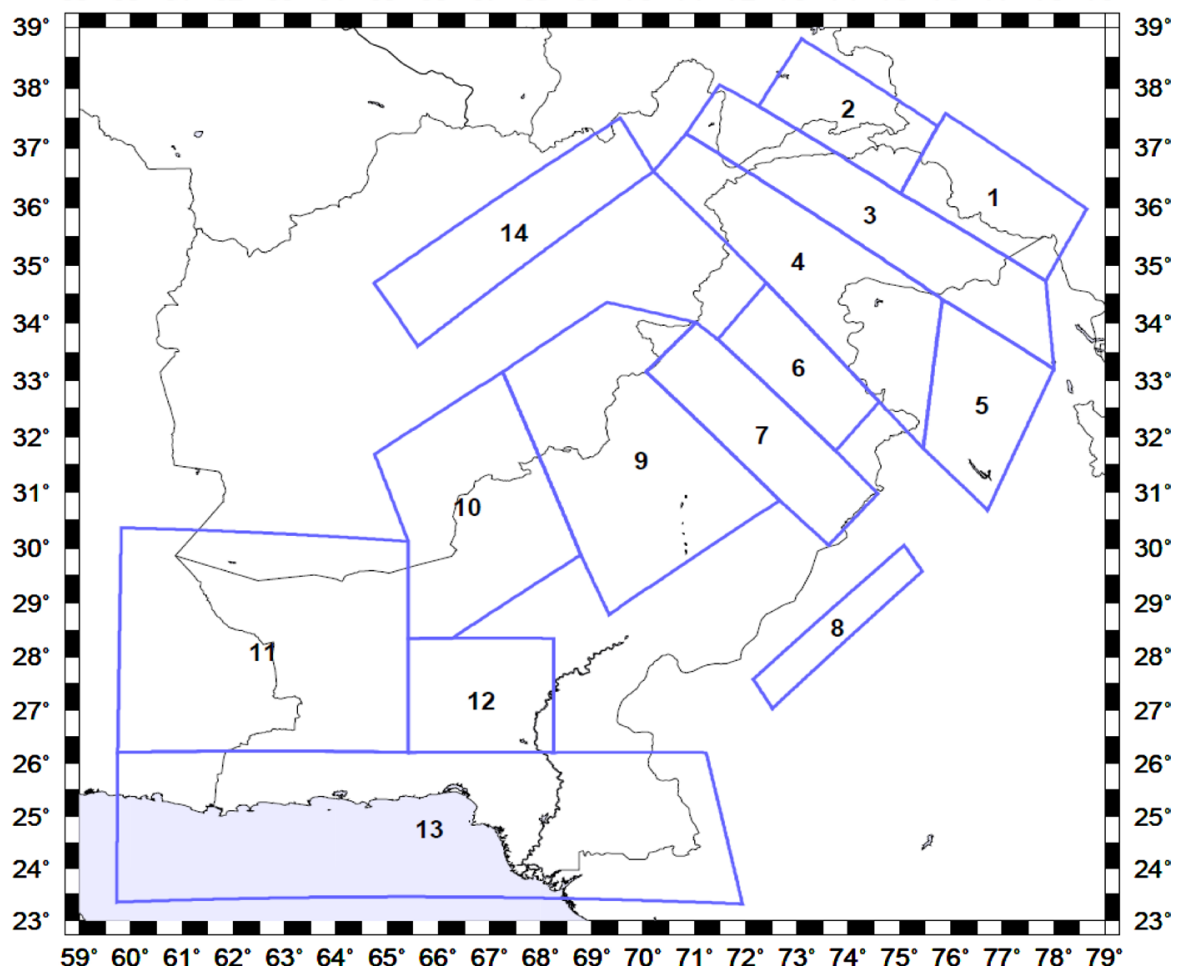

Figure 1. This figure shows 14 seismogenic zones.

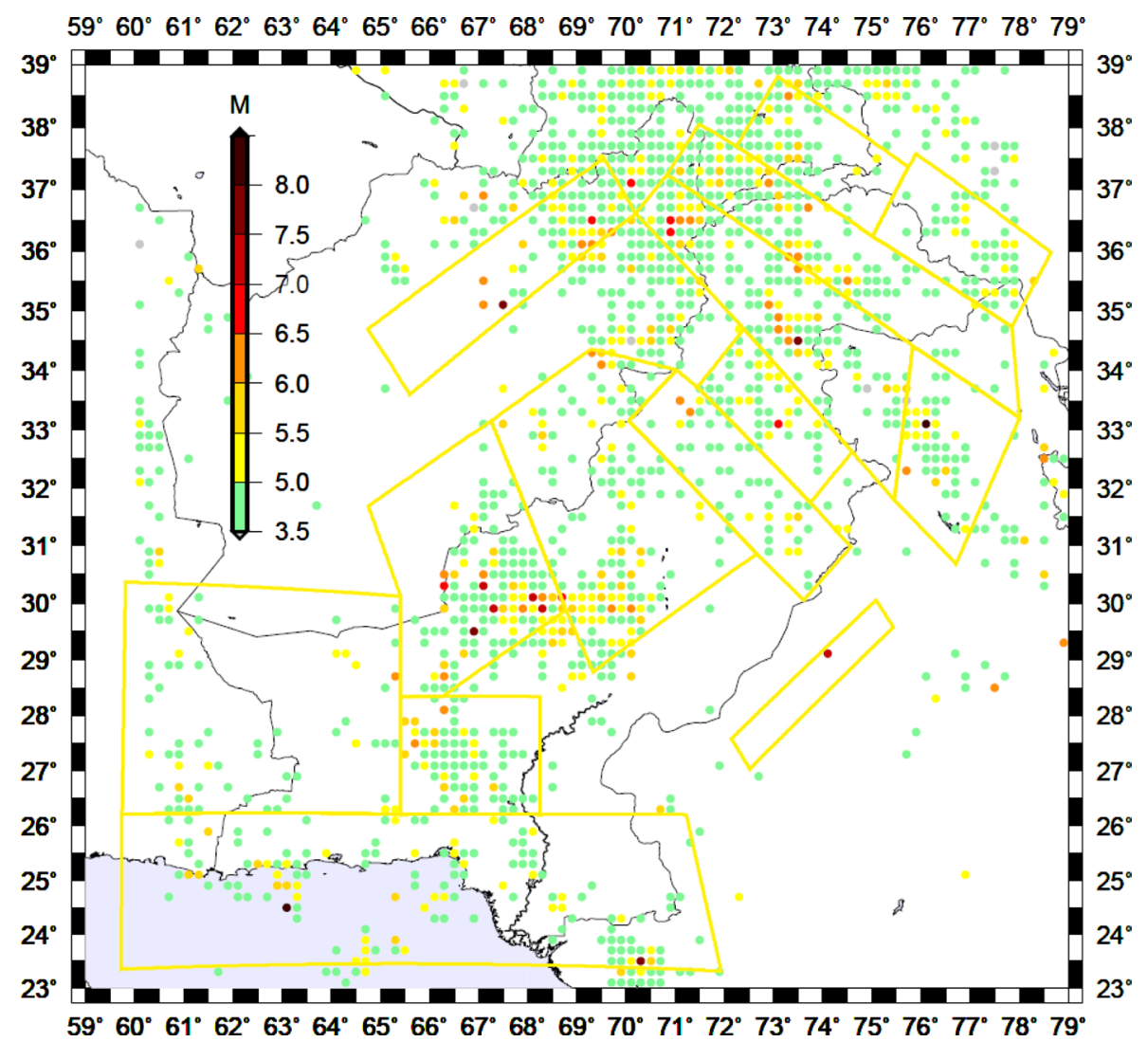

Figure 2. This figure shows the spread of seismicity for a period of 100 years. 
Pakistan appear to be seismically quiet except at the times of large earthquakes [6]. We have shown in this paper that it looks that this inactivity (or seismic gap) is at least true for the Himalayas as shown in zone-6 in the following section 3.5 and 3.6. We have seen that while conducting seismic hazard evaluation a complication may arise as we can find a seismic gap in an area and it may be found inactive for larger time periods than the monitoring record. We have also shown that while a thrust regime clearly dominates in several places of the study area, it is often difficult or impossible to associate specific seismic activity with specific fault traces, and this leads to the conclusion that many faults may be blind. A brief account of active faults and major cities in these 14 zones is given in the section from 3.1 to 3.14 .

\subsection{Zone-1}

We locate the faults present in zone- 1 are Reshun fault, Panggong-Nuchang fault, Altayan-Tagh fault systems.

The Reshun faults [7] extend from near Chitral up to Baroghil Pass towards north east. We identify that there is a significant possibility that this is an active fault as a number of teleseismic events of magnitude 3.0 to magnitude 5.0 have been recorded along this fault. The Altyn-Tagh in the northern part of the Tibetan Plateau is a strike slip fault, despite its length which accommodates a large section of plate convergence there is no of record any major earthquake in the past. The great mountains namely K-2, Gasherbrun and the Karakoram Range are present in this zone including few villages of Gilgit-Baldistan area and a small region of China, these villages namely Askole, Surungo and some other small villages with beautiful sights are all remote areas lacking all the basic facilities of life with people living in houses made of mud and stones that are highly vulnerable to every kind of disaster whether it is earthquake or floods and in case of any disaster the villages are lacking proper communication system and are at long distances from any nearby more stable areas.

\subsection{Zone-2}

We locate the faults present in zone-2 are Upper Hunza fault, Main Mantle Trust (MMT), and Tirich Mir. The Hindu Kush and Pamir are amongst the most active seismic regions of the world [8]. The Upper Hunza fault [9] is east-west oriented fault in the central Karakoram with recorded evidence of three teleseismic events of M 5.0 to M 7.0. We have marked this zone as an active zone of faulting along the upper Hunza-Reshun fault zone and the zone has Wakhan district of Afghanistan which is a very remote area that is sparsely populated and mostly people live in yurts. There is so much poverty that the people hardly make the two ends meet and cannot improve their standard of living.

\subsection{Zone-3}

We find that the Reshun, Main Karakoram Thrust (MKT), Hamran, Raikot-Sassi, Harban faults are present in zone-3. Main Karakoram Thrust (MKT) is a source of high seismic activity with a large number of earthquakes. Harman fault runs along the Harman valley and there is satisfactory information that this fault and Raikot Sassi fault is active [10].The upper Hunza valley and Gilgit valleys are situated in this zone. We find traditional housing made of timber wood, stones and mud with roofs made of metal sheets as well as some modern houses in these valleys and it has also been observed that the traditional buildings copes well with the earthquake shakings without falling apart as compared to modern concrete houses.

\subsection{Zone-4}

We have identified that zone- 4 is seismically the most active zone of Pakistan because it consist of most active faults namely the Resbun fault, Main Karakoram Thrust (MKT), Main Mantle Thrust (MMT), Sassi-Dassu, Jehlum fault, Terbela fault, Balakot-Bagh fault (BBF). A seismically active emergent thrust fault system extends stepwise from the Balakot-Bagh fault [11] [12]. The source of the 8 October 2005 earthquake of M 7.6 was the northwest-striking Balakot-Bagh (BBF) and this fault was identified before the 8 October 2005 but had not been identified active for a $16 \mathrm{~km}$ portion near Muzaffarabad [13]. We have also shown in this zone on 28 December 1974 an earthquake of magnitude 6.2 hit Hunza and areas in northern Pakistan and the village of Pattan was almost completely destroyed. We have found that general seismicity pattern of the Jhelum fault in the same zone is of low activity of regular earthquakes with magnitudes $\leq 4.0$ as the historical and the instrumental seismic data for this region show no earthquake with larger magnitude. Main cities in zone-4 are the capital city of Pakis- 
tan Islamabad, Pindi, Muree, Bagh, Muzaffarabad, Chitral, Sialkot, Gujrat, Kalam, Mangora, and Abbotabad. The Islamabad and its twin city Pindi are modern cities with better infrastructure than Muree, Chitral, and Kalam and other small cities and villages where mostly population reside in houses either made of wood or mud and stones and as could be observed from the 8 October 2005 earthquake that mostly disaster was intensified due to collapsing of these inferior quality material houses.

\subsection{Zone-5}

The zone-5 comprises Kangra Valley fault (KVF) India, which is a newly identified right lateral strike-slip active fault [14] and is capable of producing $\mathrm{M}_{\mathrm{W}} \geq 7.2$ earthquakes as paleoseismic investigations also revealed evidence of at least four earthquakes on the KVF [15]. In 1905 a devastating earthquake of $\mathbf{M}_{\mathrm{s}} 8.0$ occurred in the North West Himalayas in Kangra valley [16], we have identified that although for many years one portion of eastern Himalayan frontal thrust was inactive and this valley was completely destroyed and became inhabitant for several years but after 1960's people started resettling in the valley. The disaster was mainly due to the construction of buildings on colluvium surface meaning that this surface with the passage of time under the action of gravity the soil creeps downhill which in turn makes the building foundations weaker and even earthquakes of moderate magnitude can cause great damage.

\subsection{Zone- 6}

The fault system in zone-6 is Indus (Darband) fault, Nowshera fault, Attock (khairabad) fault, Main Boundary Thrust (MBT) (Parachinar-Hissartang-Cambellpur-Murree F.) and Jhelum fault. We have identified that this zone is a region of moderate to high seismicity having many active faults. The two active faults Attock and Nowshera faults have been mapped in [5]. We find that the Cambellpur and Attock are two parallel east-west trending active fault lineaments and numerous teleseismic events are present along these faults. The Main Boundary Thrust (MBT) represents the extensive zone of modern deformation and the devastating earthquakes. In Pakistan active faults are rather densely distributed on and in the vicinity of the MBT [17]. We find that the depths associated with numerous earthquakes occurring on the MBT are shallow with shallow northward dipping subsurface extension of the MBT underlying the MCT. The MBT spans from the border of Afghanistan to Assam through eastern India. It is the single most dominant source of earthquake in the Himalayas. Jhelum fault is the youngest and an active fault. The main cities in this zone are Attock, Gujranwala, Jehlum, and Peshawar on the boundary line of this zone and all these cities are thickly populated with buildings made of concrete blocks or bricks.

\subsection{Zone-7}

We locate the faults in zone-7 are Uchchali fault, Salt Range thrust, Kalabagh fault, Surghar thrust, Bannu basin. The Kalabagh is right lateral strike slip active fault as shown in [5] and it lies to the west of Potwar basin and aborts at the western margin of the Salt Range. The Surghar thrust fault is east west trending dip slip fault in Surghar range and is characterized by high teleseismic activity [17]. We find that the main cities in this zone are Kohat, Bannu, Kalabagh, Mianwali, Hafizabad, Chakwal, Faisalabad and Lahore, all these cities are densely populated and among these cities Lahore is the heart of Pakistan with historical places and in the same city we see two types of infrastructure on one side we see old Lahore (inner Lahore) with congested buildings with connecting roofs with neighboring houses, with roads through which transportation like motor cars or heavy vehicles cannot pass only pedestrian and motor bikes can travel easily and on the other side we come across modern Lahore with better infrastructure with wide roads and high rise modern buildings but all new and old construction lack the proper lay down of base/foundation in constructing the buildings and use concrete blocks as building material which make it vulnerable to seismic activities. On the other hand Bannu is a very poor remote area facing since many years terrorist activities and waiting for peace and prosperity.

\subsection{Zone-8}

We have located zone 8 in our studies in Rajasthan India and we establish that this zone comes is the least active seismic zone. It is seen that except a few places close to Sindh of Pakistan are safe from earthquakes. 


\subsection{Zone- 9}

We find that the fault system in this zone are Sora-Rogha fault, Mandana-Kach fault, Domanda fault, Takht-eSulaiman, Moghalkot, Manikhawa, Kingri, Kakar-Khorasan, Chaudhan-Manda, Mekhtar and Kohlu faults. We show that two left-lateral wrench faults have been identified in the eastern and western margin of the Sulaimanrange and further on the eastern side, two faults constitute a left-lateral fault system having Chaudhan fault and Domanda fault and on the western side also there is left-lateral fault system constituting Thakht-e-Sulaiman fault, Manikhawa fault and Moghulkot fault. Kingri fault is a regional north northwest-south southeast trending strike slip fault cutting the Tertiary and Mesozoic section in the Sulaiman fold and thrust belt. The main cities in this zone are Dera Ismail Khan, Zhob, Dera Ghazi Khan and Multan with moderate seismicity.

\subsection{Zone-10}

We identify the faults in this zone are Ghazaband, Chiltan Takhatu, Quetta, Johan, Mach, Harnai, Chaman, and Barkan faults. We show that the main cities in this zone are Chaman, Pishin, Quetta, Ziarat, Much, Nushki, and Kalat. In 1935 on 30 ${ }^{\text {th }}$ May, an earthquake of magnitude 7.6 rocked Quetta city, the epicenter was in the Sulaiman Range in Pakistan along the fastest moving left-lateral, strike-slip Chaman fault. As indicated by ground deformation Chiltan range and Ghazaband fault zone are also responsible for the earthquake.It was one of the deadliest quakes ever in Southeast Asia. It begins in the west from Herat, Afghanistan and moves to the east and become source of seismic activities in Pakistan and from the west of Quetta it is connected to Kirthar range. The Chaman fault zone characterizes the western boundary of this wide deformation zone. While its northern part traverses Afghanistan, the central part goes into Pakistan northwest of Quetta before it continues southwards towards the Arabian Sea [18]. We declare that the trend of seismicity in the region of the epicenter of the earthquake favors a west to north-west striking fault plane. High tectonic stresses were present in the area, as implied by the value of stress drop and the apparent stress associated with the earthquake. The 24 September 2013 Balochistan earthquake $\mathrm{M}_{\mathrm{W}}$ of 7.7 took place in southwestern Pakistan. On 28 September, M 6.8 aftershock occurred to the north at a depth of $14.8 \mathrm{~km}$. These motions are primarily accommodated on the Chaman Fault. Historically, on 24 August 1931 an earthquake of $M_{w} 6.8$ and on 27 August 1931 another earthquake of $M_{w} 7.3$ caused considerable damage in Quetta and adjoining regions [19].We find that the Quetta city is thickly populated city with infrastructure gradually changing with time, in the past double storey buildings were not permitted due to the seismic activities and buildings were made up of metal sheets, bricks, bamboo sticks, and mud and it was observed that these buildings are still better and quake proof but with passage of time people have constructed modern multi storey buildings made up of unreinforced masonry that are highly vulnerable to quakes. Another main problem is that about 40 percent of the Quetta city like satellite town is lying on dry karez system with no building code implementation, with low quality material, no restriction on the number of storey's of the building and above all non-engineered construction due to poverty, unawareness, no law and order situation, as this city is at seismic risk and any future earthquake can cause much more damage as compared to past so it is needed that not only Government but also at individual level efforts must be made to make the public aware about earthquake risk and preparedness.

\subsection{Zone-11}

We find that this zone has Mashkichah fault, Ladgasht fault, Ahmadwal fault, Dalbandin fault, Chama, Panjgur fault, Hoshab fault, Awaran fault, Bazdar fault and Jhal-Jhao fault. We establish that the Hoshab fault is one of the major thrust faults which divide the Makran region into a number of thrust bound blocks. Hoshab fault is situated in the Makran convergence zone, which is an intensely deformed, east-west trending fold and thrust belt. This fault has an arc shape having east-west trending near the Nasirabad and Hoshab areas, however eastward it swings to the north-east until it runs parallel to Mashkairud. On 18 January 2011, a Mw 7.2 earthquake occurred in Southwestern Pakistan. The location of the earthquake was $28.732^{\circ} \mathrm{N}, 63.928^{\circ} \mathrm{E}$. Its epicenter was located 50 km WSW of Dalbandin. At least three people died and several were injured. The depth of the earthquake was 84 $\mathrm{km}$. The area is dominated by both strike slip and thrust faults [19]. We find that the main cities in this zone are Nokundi, Dalbandin, Panjgur, and areas of Iran. Except January 2011 earthquake, no major seismic activity is recorded in this zone. 


\subsection{Zone-12}

We find that the zone-12 has Kirthar fault which is quite prominent north-south trending lineament on the satellite imagery and a number of earthquake epicenters are located in this region associated with this fault and with a relatively diffused seismicity as compared to that in the Suleiman range. In the latter, the seismicity falls on or near a distinct fault fragment which balance the range against the east-ward ranging Indus basin. On 27 August 1931 during the much earthquake the northern two thirds of the faults was ruptured [20]. The cities in this zone are Jacobabad, Larkana, Dadu, these cities are at low seismic risk.

\subsection{Zone-13}

We identify the faults in zone-13 are Ras Malan fault, Aghor fault, Nai-Rud fault, Ormara fault, Makran coast fault, Kulmir-Sunt fault, Surjan fault, Jhimpir fault, Hab fault, Somianni fault, Rann of Kutch and Ornarch fault.

Ornarch-Nal fault is the southeastern extension of the Chaman fault system, strike slip fault extending into the Arabian Sea in south. The southernmost segment of the Ornarch-Nal fault system starts $130 \mathrm{~km}$ due west of Karachi and extends northward for $200 \mathrm{~km}$. Based on scaling relations [21], the fault could produce an earthquake with a magnitude as large as $M_{w} 7$, or perhaps larger. Though recent faulting has been identified [6] the historical record contains no known earthquake on this segment. We establish Run of Kutch is an active fault with the evidence of many earthquakes of different magnitudes, but its extensions are not well defined both in the east and as well as in the west directions. However, two important possibilities have been suggested so far; for east ward extension, either fault extends along the axis of the great Run of Kutch or it extends to $50 \mathrm{~km}$ east of fort Sidry, where it curves North-east-ward to follow the geomorphic boundary between the Thar Desert and the great Run of Kutch. Nai-Rud fault is an active fault and has a NE-SW trending, almost parallel to the Nai-Rud valley and bears the characteristics of a thrust with left-lateral strike-slip component. The main cities in this zone are Pasni, Gawadar, Turbat, Jhal-Jhao, Karachi, Hyderabad, Nawabshah, Mirpurkhas, Bela and Thata. Among these cities Karachi is the mega city of Pakistan with many skyscrapers whereas cities like Pasni and Turbatarecities with difficult life and poorly constructed mud houses and Gawadar is a port citywhich is developing rapidly with many plans for improvement of infrastructure, roads and many other development programs to make it a fully operational Gawadar Port.

\subsection{Zone-14}

We identify that this zone contains Herat fault. This fault is seismically inactive [22] with no records of seismic activity during historic and instrumental period. There is no fault-related seismicity [23]. We observe that in the IX Century near Herat and another in 1874 north of Kabul seem to be the only events with "possible connection" to the lineament. This zone lies in the central Afghanistan and the main city in the vicinity of Heart fault is Baniyan city except for 1956 earthquake of magnitude 7.4 there is no major tectonic activity in the zone.

\section{Conclusion}

We have studied historical and recent seismic activities in Pakistan in our 14 seismogenic zones and we have found that the zones 3, 4, 6, 10 and 13 show high seismic activity and some of the major cities that are thickly populated lying in these zones like Islamabad, Karachi, Quetta, Peshawar, Gawadar, Pasni, Ziarat, and Kalat are at constant threat from future destruction. Pakistan is an earthquake prone developing nation and we need to explore more about the techniques which are supposed to be the best and rapid way to reduce or if possible, put an end to earthquake disasters in the country in future but unfortunately in a developing country like Pakistan we had to minimize our expectations and analyze why our research is not pinpointed on seismic instrumentation and monitoring, careful data analysis and catalogue production, the fundamentals of seismic hazard evaluation complementary micro-zonation studies, vulnerability, and risk assessment. We do not need a major research program but with the help of current knowledge, much can be done to reduce the potential loss of life and property from future earthquakes. In order to improve the required database for earthquake prediction research and applications, both quantitatively and qualitatively, large country-wide digital sensor networks comprising different types of monitor should be deployed. There is increasing need on long-term disaster preparedness and mitigation efforts based on improved seismic hazard assessment, micro-zonation, earthquake resistant construction, etc. Quite a few contributions to the probabilistic approach to seismic hazard assessment have been made in the Pakistan. 
Although earthquakes cannot be predicted but as all major cities of Pakistan are located on the fault line, we must take every step to ensure every possible measure to protect the country from future disaster. Now people are well aware of the fact that earthquakes are not the cause of killing the people, and the destruction is mainly due to collapsing of the buildings. This is certainly largely true for earthquakes in Pakistan where hardly some structures resistant to earthquake exist and mostly the buildings are highly vulnerable to earthquake. It is the pressing need of the time to develop new building codes and they should strictly be implemented.

\section{References}

[1] Atkinson, G.M. (2004) An Overview of Developments in Seismic Hazard Analysis. Proceedings of the 13th World Conference on Earthquake Engineering, Vancouver, 1-6 August 2004.

[2] Kazmi, A.H. and Rana, R.A. (1982) Tectonic Map of Pakistan, Geological Survey of Pakistan.

[3] Farhana, S., Saleem, I. and Lalarukh, K. (2011) An Analysis of Pakistan's Local Network Catalog of Earthquake for the Period of 1905-2007. Science International (Lahore), 23, 13-18.

[4] Parvez, I.A., Vaccari, F. and Panza, G.F. (2003) A Deterministic Seismic Hazard Map of India and Adjacent Areas. Geophysical Journal International, 155, 489-508. http://dx.doi.org/10.1046/j.1365-246X.2003.02052.X

[5] Kazmi, A.H. (1979) Active Fault System in Pakistan. In: Farah, A. and De Jong, K.A., Eds., Geodynamics of Pakistan: Geological Survey of Pakistan Quetta, Pakistan, 285-294.

[6] Nakata, T., Tsutsumi, H., Khan, S.H. and Lawrence, R.D. (1991) Active Faults of Pakistan: Map Sheets and Inventories (Special Publication). Research Center for Regional Geography, Hiroshima University, 141.

[7] Calkins, J.A., Jamiluddin, S., Bhuyan, K. and Hussain, A. (1981) Geology and Mineral Resources of the Chitral-Partsan Area, Hindu-Kush Range. Northern Pakistan USGS Professional Paper 761-G, BiblioGov, USA, 1-3.

[8] Nowroozi, A.A. (1971) Seismo-Tectonics of the Persian Plateau, Eastern Turkey, Caucasus and Hindu-Kush Regions. Bulletin of the Seismological Society of America, 61, No. 2.

[9] Gaetani, M., Angiolini, L., Garzanti, E., Jadoul, F., Leven, E.Ya., Nicora, A. and Sciunnach, D. (1995) Permian Stratigraphy in the Northern Karakorum, Pakistan. RivistaItaliana di Paleontologia e Stratigrafia, 101, 107-152.

[10] Kazmi, A.H. and Jan. M.Q., Eds. (1997) Geology and Tectonics of Pakistan. Graphic Publisher, Karachi, 554 p.

[11] Kaneda, H., et al. (2008) Surface Rupture of the 2005 Kashmir, Pakistan, Earthquake, and Its Active Tectonic Implications. Bulletin of the Seismological Society of America, 98, 521-557. http://dx.doi.org/10.1785/0120070073

[12] Kumahara, Y. and Nakata, T. (2006) Active Faults in the Epicentral Area of the 2005 Pakistan Earthquake. Hiroshima University Research Center for Regional Geography, Hiroshima, 54 p.

[13] Hussain, R.S. and Yeats, M. (2009) Geoligical Setting of the 8 October 2005 Kashmir Earthquake. Journal of Seismology, 13, 315-325.

[14] Malik, J.N., Sahoo, S., Okumura, K., Mohanty, A. and Naik, S.P. (2013) Evidence of Right Lateral Strike-Slip Active Fault in Kangra Valley, NW Himalaya, India. http://www.adsabs.harvard.edu/abs/2013AGUFM.T23C2608M

[15] Malika, J.N., Sahooa, S., Satuluria, S. and Okumurab, K. (2015) Active Fault and Paleoseismic Studies in Kangra Valley: Evidence of Surface Rupture of a Great Himalayan 1905 Kangra Earthquake $\left(\mathrm{M}_{\mathrm{w}} 7.8\right)$, Northwest Himalaya, India. Bulletin of the Seismological Society of America, 105, 2325-2342. http://dx.doi.org/10.1785/0120140304

[16] Middlemiss, C.S. (1910) The Kangra Earthquake of 4th April, 1905. Member Geological Survey of India, 38, 1-409.

[17] Nakata, T. (1989) Active Faults of the Himalaya of India and Nepal. GSA Special Papers, 232, 243-264. http://dx.doi.org/10.1130/SPE232-p243

[18] PMD (2007) Seismic Reports. Pakistan Meteorological Department. http://www.pakmet.com.pk/SeismicReport_PMD.pdf

[19] John Wiley \& Sons Ltd. (2015) Geology Today, the Geologists’ Association \& the Geological Society of London. Vol. 31, No. 1.

[20] West, W.D. (1934) The Baluchistan Earthquake of 25th and 27th Aug 1931. Memoirs of Geological Survey, India, 67, 01-82.

[21] Wells, D.L. and Coppersmith K.J. (1994) New Empirical Relationships among Magnitude, Rupture Length, Rupture width, Rupture Area, and Surface Displacement. Bulletin of the Seismological Society of America, 84, 974-1002.

[22] Quittmeyer R.C. and Jacob, K.H. (1979) Historical and Modern Seismicity of Pakistan, Afghanistan, NW India and SE Iran. Bulletin of the Seismological Society of America, 69, 773-823.

[23] Verma R.K., Mukhopadhyay, M. and Bhanja, A.K. (1980) Seismotectonics of the Hindukush and the Baluchistan Arc. Tectonophysics, 66, 301-322. http://dx.doi.org/10.1016/0040-1951(80)90247-4 